\title{
COVID-19 Tanısıyla Takip Edilen Hastalarda Annexin-1 (ANXA-1), Annexin-2 (ANXA-2) ve Kemik Morfogenetik Protein-7 (BMP-7) Serum Düzeyinin Değerlendirilmesi
}

\section{Evaluation of Annexin-1 (ANXA-1), Annexin-2 (ANXA-2) and Bone Morphogenetic Protein-7 (BMP-7) Serum Levels in Patients Followed Up With A Diagnosis of COVID-19}

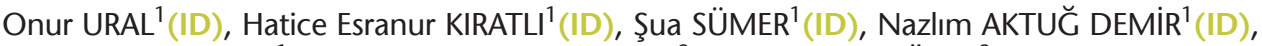 \\ Sema YILMAZ KIRIK ${ }^{1}(I D)$, Hüsamettin VATANSEV²(ID), Fikret AKYÜREK²(ID), \\ Hakan $\operatorname{CEBECi}^{3}\left(\right.$ ID), Uğur ARSLAN ${ }^{4}$ (ID), Lütfi Saltuk DEMiR ${ }^{5}$ (ID) \\ ${ }^{1}$ Selçuk Üniversitesi Tıp Fakültesi, Enfeksiyon Hastalıkları ve Klinik Mikrobiyoloji Anabilim Dalı, Konya. \\ 1 Selcuk University Faculty of Medicine, Department of Infectious Diseases and Clinical Microbiology, Konya, Turkey. \\ ${ }^{2}$ Selçuk Üniversitesi Tıp Fakültesi, Tıbbi Biyokimya Anabilim Dalı, Konya. \\ 2 Selcuk University Faculty of Medicine, Department of Medical Biochemistry, Konya, Turkey. \\ ${ }^{3}$ Selçuk Üniversitesi Tıp Fakültesi, Radyoloji Anabilim Dalı, Konya. \\ 3 Selcuk University Faculty of Medicine, Department of Radiology, Konya, Turkey. \\ ${ }^{4}$ Selçuk Üniversitesi Tıp Fakültesi, Tıbbi Mikrobiyoloji Anabilim Dalı, Konya. \\ ${ }^{4}$ Selcuk University Faculty of Medicine, Department of Medical Microbiology, Konya, Turkey \\ ${ }_{5}^{5}$ Necmettin Erbakan Üniversitesi Tıp Fakültesi, Halk Sağlığı Anabilim Dalı, Konya. \\ ${ }^{5}$ Necmettin Erbakan University Faculty of Medicine, Department of Public Health, Konya, Turkey.
}

*Bu çalışma, 31. ECCMID (09-12 Temmuz 2021, Basel, isviçre) poster bildiri olarak sunulmuştur. Bu çalışma, Selçuk Üniversitesi Bilimsel Araştırma Projeleri Koordinasyon Birimi tarafından desteklenmiştir (Proje No: 20301007).

Makale Atıfı: Ural O, Kıratı HE, Sümer Ş, Aktuğ Demir N, Yılmaz Kırık S, Vatansev H ve ark. COVID-19 tanısılla takip edilen hastalarda Annexin-1 (ANXA-1), Annexin-2 (ANXA-2) ve kemik morfogenetik Protein-7 (BMP-7) serum düzeyinin değerlendirilmesi. Mikrobiyol Bul 2022;56(1):25-35.

\section{öz}

Koronavirüs hastalığı 2019 (COVID-19), şiddetli akut solunum yolu sendromu-koronavirüs-2 (SARSCoV-2)'nin neden olduğu küresel bir sağlık sorunudur. SARS-CoV-2 enfeksiyonu; asemptomatik veya hafif formdan, yoğun bakım takibi ve mekanik ventilasyon gerektiren solunum yetmezliğine kadar değişen klinik tablolarla karşımıza çıkabilmektedir. Bu hastalığın farklı klinik tablolarla seyretmesi birçok immünolojik soruyu gündeme getirmiştir. Bu çalışmada, COVID-19 tanısı alan hastalarda annexin-1 (ANXA-1), annexin-2 (ANXA-2) ve kemik morfogenetik protein-7 (BMP-7) serum düzeylerinin değerlendirilmesi ve bu belirteçlerin akciğer tutulumu ile ilişkili olup olmadığının araştıııması amaçlanmıştır. Çalışma, COVID-19 tanısı ile takip ve tedavi edilen 173 hasta ve 51 sağlıklı kontrol grubunda gerçekleştirilmiştir. Hastalar öncelikle akciğer bilgisayarlı tomografi (BT) taramalarında COVID-19 için tipik akciğer tutulumu (buzlu cam opasiteleri, konsolidasyon ve her ikisinin birlikte olması) varlığına göre iki gruba ayrılmıştır. Akciğer

İletişim (Correspondence): Dr. Hatice Esranur Kıratlı, Selçuk Üniversitesi Tıp Fakültesi, Enfeksiyon Hastalıkları ve Klinik Mikrobiyoloji Anabilim Dalı, Alaeddin Keykubat Kampüsü, Konya, Türkiye. Tel (Phone): +903322244962, E-posta (E-mail): esranurkiratli@gmail.com 
BT taramalarında tutulumu olduğu tespit edilenler, lezyonlarının yaygınlığına göre hafif $(<\% 33)$, orta (\%34-66), ve ağır (> \%67) tutulum olmak üzere üç gruba ayrılmıştır. Çalışmaya dahil edilen 173 hastanın 130'unda COVID-19 için tipik akciğer BT tutulumu varken, 43'ünde tespit edilmemiştir. Hastalarda ANXA-1, ANXA-2 ve BMP-7 değerleri kontrol grubundan yüksek saptanmıştır ( $p=0.001, p=0.001, p=$ $0.001)$. ANXA-2 düzeyleri, akciğer BT tutulumu olan hastalarda olmayanlardan yüksek tespit edilmiştir $(p=0.023)$. Ayrıca hastalar akciğer BT tutulum seviyelerine göre değerlendirildiğinde, tutulum seviyeleri arttıkça ANXA-2'nin arttığı, ANXA-1'in azaldığı, BMP-7 düzeylerinin ise değişmediği tespit edilmiştir. ANXA-2'deki artış istatistiksel olarak anlamlıyken, ANXA-1'deki düşüş istatistiksel olarak anlamlı bulunmamıştır. Laboratuvar parametrelerinin akciğer BT tutulum seviyesi ile ilişkisi değerlendirildiğinde akciğer $B T^{\prime}$ de tutulum arttıkça lenfosit ve trombosit sayılarının azaldığı; laktat dehidrogenaz (LDH), ferritin, prokalsitonin (PCT), C-reaktif protein (CRP), D-dimer ve troponin değerlerinin arttığı görülmüştür. ANXA-1 ve BMP-7 ile laboratuvar parametreleri arasında anlamlı bir korelasyon saptanmazken, ANXA-2 ile lökosit sayısı, LDH, troponin, PCT, ferritin, D-dimer, CRP arasında pozitif korelasyon tespit edilmiştir. Çalışmamızda elde edilen veriler, başvuru anındaki ANXA-2 düzeyinin, hastalığın akciğer tutulumu ve tutulum düzeyi ile ilişkili olduğunu düşündürmektedir. Sonuç olarak, günümüzde COVID-19 patogenezini anlamak ve yeni tedavi hedeflerini araştırmak için moleküler çalışmalara gereksinim bulunmaktadır. ANXA-2 düzeyinin değerlendirilmesi COVID-19'a bağlı akciğer tutulum düzeyini öngörmede önemli olabilir.

Anahtar kelimeler: Annexin-1; annexin-2; bmp-7; COVID-19.

\section{ABSTRACT}

Coronavirus disease 2019 (COVID-19) is a global health problem caused by severe acute respiratory syndrome coronavirus-2 (SARS-CoV-2). SARS-CoV-2 infection may present with clinical pictures ranging from asymptomatic or mild forms to respiratory failure requiring intensive care follow-up and mechanical ventilation. The course of this disease with different clinical presentations raises many immunological questions. This study aimed to evaluate the serum levels of Annexin-1 (ANXA-1), Annexin-2 (ANXA-2) and bone morphogenetic protein-7 (BMP-7) in patients diagnosed with COVID-19 and to investigate whether these markers are associated with lung involvement. The study was conducted in 173 patients who were followed and treated with the diagnosis of COVID-19 and 51 healthy control group. Patients were primarily divided into two groups based on the presence of typical lung involvement (ground glass opacities, consolidation, and both) in the thoracic computed tomography (CT) scans for COVID-19. Those who found to have involvement in thoracic CT scans were divided into three groups as mild (< $33 \%)$, moderate (34-66\%), and severe (>67\%) according to the extent of their lesions. Of the 173 patients included in the study, 130 had typical thoracic CT involvement for COVID-19, while 43 did not. ANXA-1, ANXA-2 and BMP-7 values were found to be higher in the patients than the control group ( $p=$ $0.001, p=0.001, p=0.001$ ). ANXA-2 levels were higher in patients with thoracic CT involvement than those without thoracic $C T$ involvement $(p=0.023)$. In addition, when the patients were evaluated according to their thorax $C T$ involvement levels, it was found that as the lung involvement levels increased, ANXA-2 increased, ANXA-1 decreased, and BMP-7 levels did not change. While the increase in ANXA-2 was statistically significant, the decrease in ANXA-1 was not found statistically significant. When the relationship between the laboratory parameters and the thorax CT involvement level was evaluated; it was found that, the lymphocyte and thrombocyte counts decreased as the thorax CT involvement increased, and lactate dehydrogenase (LDH), ferritin, procalcitonin (PCT), C-reactive protein (CRP), D-dimer and troponin levels were increased. While no significant correlation was found between ANXA-1 and BMP-7 and laboratory parameters, a positive correlation was found between ANXA-2 and leukocyte count, LDH, troponin, PCT, ferritin, D-dimer, and CRP. The data obtained in our study suggest that the ANXA-2 level at the time of admission was related with the lung involvement and the level of involvement of the disease. As a result, molecular studies are needed today to understand the pathogenesis of COVID-19 and to investigate new treatment targets. Evaluation of ANXA-2 level may be important in predicting the level of lung involvement due to COVID-19.

Keywords: Annexin-1; annexin-2; bmp-7; COVID-19. 


\section{Giriş}

Koronavirüs hastalığı 2019 (COVID-19), şiddetli akut solunum yolu sendromu koronavirüs 2 (SARS-CoV-2)'nin neden olduğu küresel bir sağlık sorunudur. SARS-CoV-2 enfeksiyonu asemptomatik veya hafif şekilden, yoğun bakım takibi ve mekanik ventilasyon gerektiren solunum yetmezliğine kadar değişen klinik tablolarla karşımıza çıkabilmektedir. Bu hastalığın farklı klinik tablolarla seyretmesi birçok immünolojik soruyu gündeme getirmektedir ${ }^{1}$.

Enfeksiyonlarda enflamasyonun çözülmesinin aktif ve sıkı kontrol edilen bir süreç olduğu bilinmektedir. Özgül "pro-resolving" mediyatörlerin bu süreçte önemli rol oynadığı düşünülmektedir² ${ }^{2}$ Bu moleküllerden olan annexin-A1 (ANXA-1) ve annexin-A2 (ANXA-2), kalsiyum bağımlı fosfolipit bağlayıcı yapısal ilişkili protein süper ailesinin üyesidir. ANXA-1, endositoz, ekzositoz, sinyal iletimi, proliferasyon, farklılaşma, apopitoz, invazyon, migrasyon, enflamasyon gibi çok çeşitli fizyolojik ve patolojik süreçlerde rol oynar. Ayrıca ANXA-1, temel olarak anti-enflamatuvar ve anti-fibrotik süreçlerin düzenlenmesinde rol almaktadır ${ }^{3}$. Enflamasyonun çözülmesi, ANXA-1 gibi makromoleküller ve proteinleri içeren endojen faktörler tarafından kontrol edilmektedir ${ }^{2,4}$. Sitokin fırtınasının kontrolünde ANXA-1'in önemli bir mediyatör olduğu bildirilmiştir ${ }^{5}$.

ANXA-2, endotel hücreleri, monositler, makrofajlar, dendritik hücreler, epitel hücreleri ve tümör hücreleri tarafından üretilir ${ }^{6,7}$. ANXA-2'in pro-enflamatuvar etkili olduğu, vasküler sızıntı ile parankimal dokuya plazmanın sızmasına neden olarak, akciğer hasarının patofizyogenezinde ve pulmoner fibrozis mekanizmasında rol aldığı bilinmektedir ${ }^{8}$.

Kemik morfogenetik protein-7 (BMP-7) ise "transforming growth factor" (TGF) - $\beta$ süper ailesinin bir üyesidir. BMP-7 proliferasyon, hücresel farklılaşma ve apopitozun düzenlenmesinde görev almaktadır. Bu protein, anti-enflamatuvar, anti-fibrotik özelliğe sahiptir ${ }^{9}$.

COVID-19' da miyokardiyal ve akut böbrek hasarı varlığının artan mortalite ile ilişkili olduğu gösterilmiştir. Bu hastaların büyük çoğunluğu, akut respiratuvar distres sendromu (ARDS), irreversibl pulmoner fibrozis ve multiorgan yetmezliğinden kaybedilmektedir. BMP-7 sinyal yolağının aktivasyonu, COVID-19 patogenezinden sorumlu enflamasyon, apopitozis ve fibrozisi inhibe ederek çoklu organ hasarı ve pulmoner fibrozisin önlenmesine bağlı mortalitenin azaltılmasında önemli bir tedavi hedefi olabilmektedir9,10.

ANXA-1 ve BMP-7'nin anti-enflamatuvar ve anti-fibrotik, ANXA-2'nin ise proenflamatuvar ve fibrotik etkisi nedeniyle bu çalışmada üç molekülün COVID-19 hastalarındaki serum düzeyleri ve akciğer tutulumu ile ilişkili olup olmadığının araştırılması amaçlanmıştır.

\section{GEREÇ ve YÖNTEM}

Bu çalışma, Selçuk Üniversitesi Tıp Fakültesi Etik Kurulu (Karar No: 2020/13 ve Tarih: 10.07.2020) ve T.C. Sağlık Bakanlığı (Karar No: 2020-06-05T11_00_33 ve Tarih: 09.06.2020) onayı ile gerçekleştirildi. 
Çalışma, Selçuk Üniversitesi Tıp Fakültesi Hastanesinde, SARS-CoV-2 gerçek zamanlı revers transkriptaz polimeraz zincir reaksiyonu (rRT-PCR) sonucu pozitif olan, COVID-19 tanısı ile takip ve tedavi edilen 173 hasta ve 51 sağlıklı kontrol grubunda gerçekleştirildi.

On sekiz yaş ve altında olan, gebe veya başka bir nedenle hastanede yatarken COVID-19 tanısı konulan hastalar çalışmaya dahil edilmedi. Hastalar ilk önce akciğer bilgisayarlı tomografi (BT) tutulumuna göre; i) COVID-19 için tipik akciğer BT tutulumu olan hastalar ve ii) COVID-19 için akciğer BT tutulumu olmayan hastalar olarak iki gruba ayrıldı.

Akciğer BT'de COVID-19 için tipik tutulum bulgusu (buzlu cam opasiteleri, konsolidasyon ve her ikisinin birlikte olması) olan hastalar daha sonra lezyonlarının yaygınlığına göre kendi aralarında üç gruba ayrıldı.

i. Hafif tutulum: Akciğer BT tutulumu $<\% 33$ olan hastalar.

ii. Orta tutulum: Akciğer BT tutulumu \%34-66 arasında olan hastalar.

iii. Ağır tutulum: Akciğer BT tutulumu > \%67 olan hastalar.

Hastaların hemogram, CRP, D-dimer, ferritin, LDH, troponin, PCT laboratuvar değerlerine, SARS-CoV-2 PCR sonucuna ve akciğer BT'lerine hastanemiz veri tabanından ulaşıldı. Hastaların başvuru anında rutin tetkikler için alınan kanlarından artan serum örnekleri Selçuk Üniversitesi Tıp Fakültesi Biyokimya Anabilim Dalı (AD) Laboratuvarında $-80^{\circ} \mathrm{C}$ 'de çalışma gününe kadar saklandı.

\section{BMP-7, ANXA-1 ve ANXA-2'nin Saptanması}

Selçuk Üniversitesi Tıp Fakültesi Biyokimya AD Laboratuvarında BMP-7 (Elabscience, Katalog No: E-EL-H0013, ABD), ANXA-1 (Elabscience, Katalog No:E-EL-H5512, ABD) ve ANXA-2 (Elabscience, Katalog No:E-EL-H0448, ABD) molekülleri serum örneklerinde "enzyme-linked immunosorbent assay (ELISA)" yöntemi ile çalışıldı.

Insan ANXA-1, ANXA-2 ve BMP-7 konsantrasyonlarının serumdaki tespiti, özgül antikor ile kaplanmış 96 kuyucuklu ELISA mikroplaklarına numuneler eklenip inkübe edilerek gerçekleştirildi. Aspirasyonun ardından araştııılan molekül ve "avidin-horseradish peroxidase (HRP)" konjugatına özgü biyotinlenmiş saptama antikoru, her bir kuyucuğa eklendi ve tekrar inkübe edildi. Daha sonra sırasıyla üç ve beş tekrarlı yıkama yapıldı. Ardından substrat solüsyonu her kuyucuğa eklenerek renk değişimi gözlendi. Enzim-substrat reaksiyonu stop solüsyonunun eklenmesiyle durduruldu ve rengin maviden sarıya döndüğü görüldü. Optik dansite, $450 \mathrm{~nm} \pm 2 \mathrm{~nm}$ dalga boyunda spektrofotometrik olarak ölçüldü. Standartlara göre oluşturulan konsantrasyon grafiğinden faydalanılarak sonuçlar her bir molekül için ayrı ayrı değerlendirildi.

\section{İstatistiksel Analiz}

Verilerin normallik analizi Kolmogorov-Smirnow ve Shapiro Wilk-W testi ile gerçekleştirildi. İkili grup analizlerinde Mann Whitney $U$ testi, üç ve üzeri grup analizlerinde Krus- 
kall Wallis testi, post hoc olarak Bonferroni düzeltmeli Mann Whitney U testi kullanıldı. $\mathrm{P}<0.05$ istatistiksel olarak anlamlı kabul edildi.

\section{BULGULAR}

Bu çalışma, 173 hasta, 51 sağlıklı kontrol grubu olmak üzere 224 kişi üzerinde yapılmıştır. Hasta ve kontrol grubunun demografik özellikleri Tablo I'de verilmiş̧ir. Gruplar arasında yaş ve cinsiyet açısından istatistiksel olarak anlamlı bir fark tespit edilmemiştir $(p>0.05)$.

Hastalarda ANXA-1, ANXA-2 ve BMP-7 değerleri kontrol grubundan yüksek saptanmıştır (ANXA-1; $p=0.001, A N X A-2 ; p=0.001$, BMP-7; $p=0.001$ ). Hastaların ve kontrol grubunun ANXA-1, ANXA-2, BMP-7 değerleri Şekil 1, 2, 3 ve Tablo I'de verilmiştir.

Çalışmaya dahil edilen 173 hastanın 130'unda COVID-19 için tipik akciğer BT tutulumu varken, 43'ünde bulunmamıştır. Akciğer BT tutulumu olan hastaların yaş ortalaması 50 (18-92), tutulumu olmayan hastaların ise 35 (19-90) olarak bulunmuştur. Akciğer BT tutulumu olan hastaların yaşları, akciğer BT tutulumu olmayanlardan yüksek saptanırken $(p=0.001)$, cinsiyet açısından fark tespit edilmemiştir $(p=0.824)$.

Akciğer BT'de tipik tutulumu olan 130 hastanın tomografideki lezyonlarının yaygınlığına göre 102'si hafif, 15'i orta, 13'ü ağır tutulum olarak sınıflandırılmıştır. Bu hasta grubunun yaş ve cinsiyetleri değerlendirildiğinde yaş arttıkça akciğerdeki tutulumun daha yüksek olduğu gözlenirken ( $p=0.001)$, akciğerdeki tutulum düzeyi ile cinsiyet arasında fark tespit edilememiştir $(p=0.130)$.

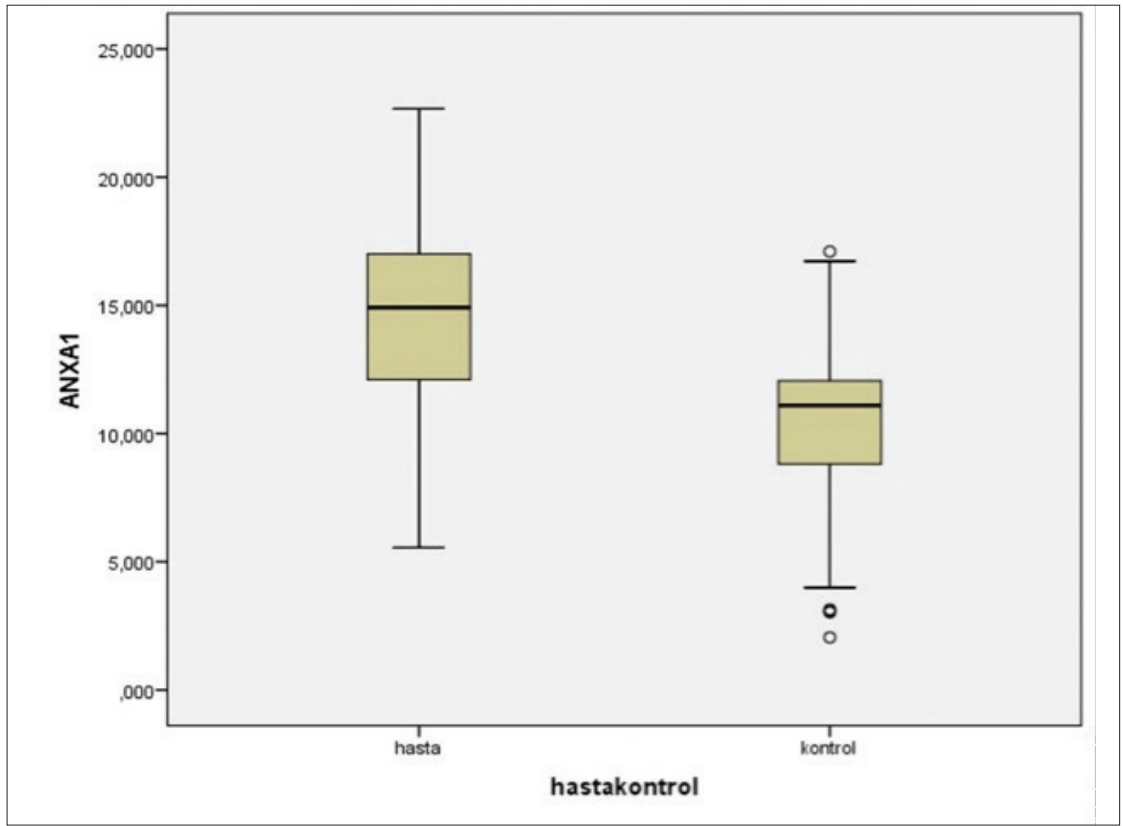

Şekil 1. Hastaların ve kontrol grubunun ANXA-1 değeri. 


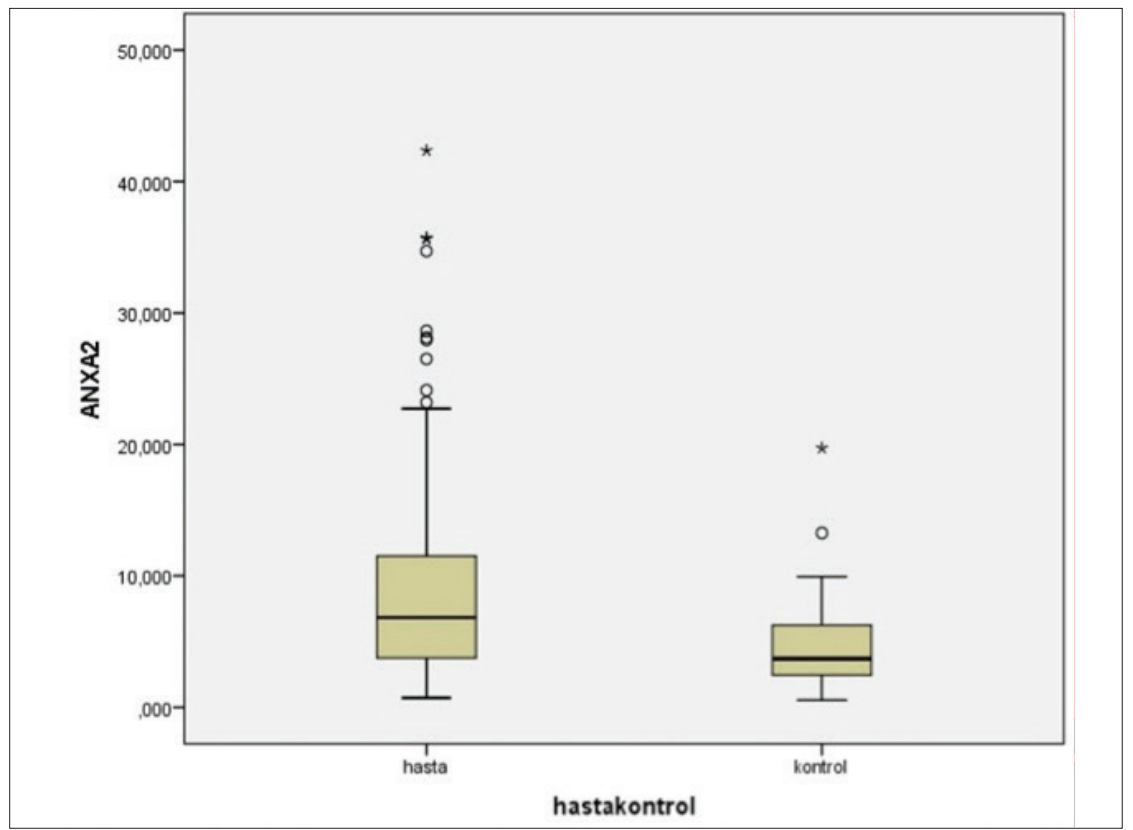

Şekil 2. Hastaların ve kontrol grubunun ANXA-2 değeri.

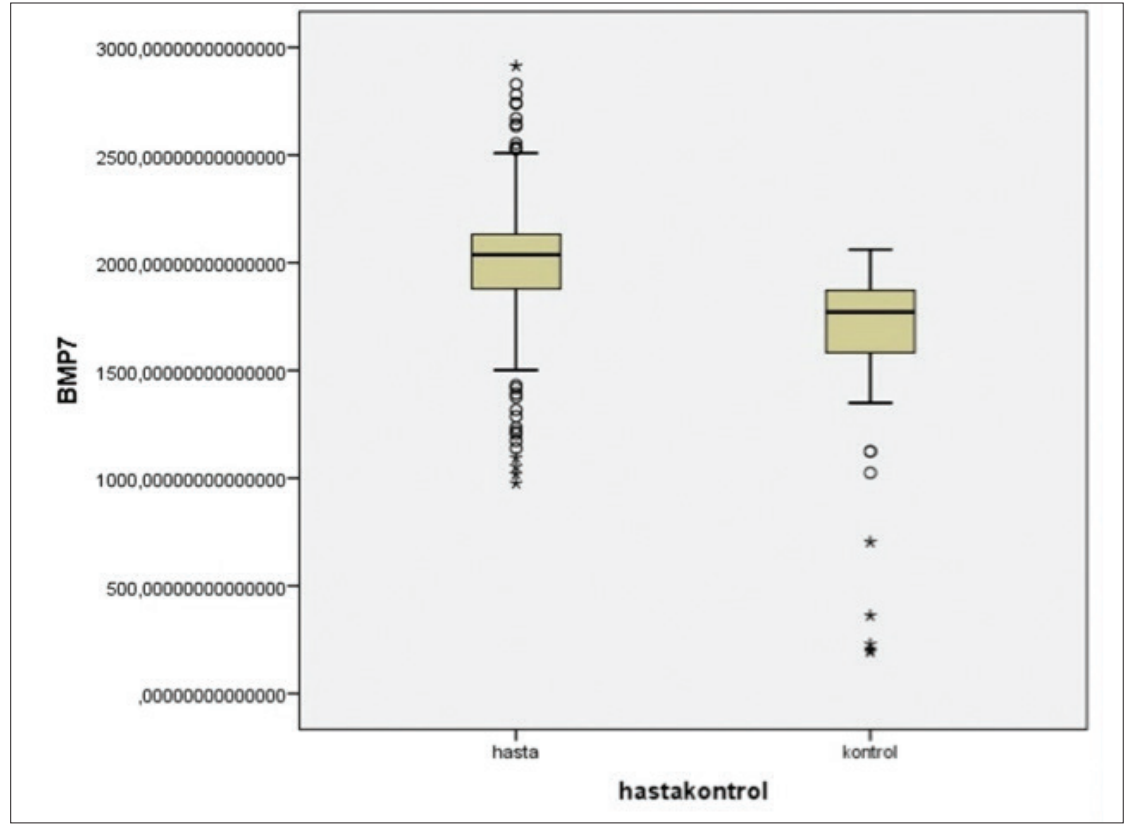

Şekil 3. Hastaların ve kontrol grubunun BMP-7 değeri. 


\begin{tabular}{|c|c|c|c|}
\hline & Hasta $(n=173)$ & Kontrol $(n=51)$ & $p$ \\
\hline Yaş & $44(18-92)$ & $40(29-59)$ & 0.132 \\
\hline Kadın & $83(\% 48.0)$ & $26(\% 51)$ & 0.706 \\
\hline Erkek & $90(\% 52.0)$ & $25(\% 49)$ & \\
\hline ANXA-1 & $14.92(5.5-22.6)$ & $11.1(2.0-17.1)$ & 0.001 \\
\hline ANXA-2 & $6.8(0.7-59.2)$ & $3.6(0.5-19.7)$ & 0.001 \\
\hline BMP-7 & $2037.5(972.2-2913.5)$ & $1771.1(193.3-2061.5)$ & 0.001 \\
\hline
\end{tabular}

ANXA-1: Annexin-A1, ANXA-2: Annexin-A2, BMP-7: Kemik morfogenetik protein-7.

\begin{tabular}{|lccccc}
\hline \multicolumn{5}{l}{ Tablo II. Akciğer Tutulum Düzeyine Göre Hastaların ANXA-1, ANXA-2, BMP-7 Değerleri } \\
\hline & $\begin{array}{c}\text { Hafif tutulum } \\
(\mathbf{n}=\mathbf{1 0 2})\end{array}$ & $\begin{array}{c}\text { Orta tutulum } \\
(\mathbf{n}=\mathbf{1 5})\end{array}$ & $\begin{array}{c}\text { Ağır tutulum } \\
(\mathbf{n}=\mathbf{1 3})\end{array}$ & $\mathbf{p}$ \\
\hline ANXA-1 & $15.5(6.2-22.6)$ & $15.0(5.5-20.7)$ & $14.5(10.9-17.6)$ & 0.540 \\
ANXA-2 & $7.3(1.0-19.6)$ & $8.4(2.5-38.6)$ & $9.4(2.8-59.2)$ & $\mathbf{0 . 0 0 3}$ \\
BMP-7 & $2047.0(1018.7-2913.5)$ & $1954.2(975.2-2742.1)$ & $2090.5(1542.3-2553.7)$ & 0.199 \\
\hline
\end{tabular}

ANXA-1: Annexin-A1, ANXA-2: Annexin-A2, BMP-7: Kemik morfogenetik protein-7.

Akciğer BT tutulumu olan ve olmayan hastalar arasında BMP-7 ve ANXA-1 değerlerinde anlamlı fark tespit edilmemiştir. ANXA-2 düzeyleri ise akciğer BT tutulumu olan hastalarda olmayanlardan yüksek saptanmıştır $(p=0.023)$. Hastalar akciğer BT tutulum seviyelerine göre değerlendirildiğinde, tutulum seviyeleri artıkça ANXA-2'nin arttığı, ANXA-1'in azaldığı, BMP-7 düzeylerinin ise değişmediği tespit edilmiştir. ANXA-2'deki artış istatistiksel olarak anlamlıyken ANXA-1'deki düşüş istatistiksel olarak anlamlı bulunmamıştır (Tablo II).

Akciğer BT tutulumu olan grupta LDH, CRP, PCT, D-dimer ve ferritin değerleri, akciğer BT tutulumu olmayan gruptan yüksek tespit edilirken lökosit sayısı, lenfosit sayısı ve trombosit sayısı açısından fark saptanmamıştır (Tablo III).

Laboratuvar parametrelerinin akciğer BT tutulum seviyesi ile ilişkisi değerlendirildiğinde; akciğer BT'de tutulum arttıkça lenfosit ve trombosit sayılarının azaldığı; LDH, ferritin, PCT, CRP, D-dimer ve troponin değerlerinin arttığı görülmüştür (Tablo IV).

ANXA-1 ve BMP-7 ile laboratuvar parametreleri arasında anlamlı bir korelasyon saptanmazken, ANXA-2'nin lökosit sayısı, LDH, troponin, PCT, ferritin, D-dimer, CRP arasında pozitif korelasyon tespit edilmiştir (Tablo V). 
Tablo III. Akciğer BT Tutulumu Olan ve Olmayan Hastaların Laboratuvar Parametrelerinin Karşılaştırılması

\begin{tabular}{lccc}
\hline & $\begin{array}{c}\text { Akciğer BT tutulumu } \\
\text { olan }(\mathbf{n}=130)\end{array}$ & $\begin{array}{c}\text { Akciğer BT tutulumu } \\
\text { olmayan }(\mathbf{n}=\mathbf{4 3})\end{array}$ & $\mathbf{p}$ \\
\hline Lökosit sayısı $(3.5-10.2 \mathrm{~K} / \mathrm{ul})$ & $6.0(2.7-22.0)$ & $6.0(2.4-14.0)$ & 0.698 \\
Lenfosit sayısı $(0.9-2.9 \mathrm{~K} / \mathrm{ul})$ & $1.2(0.2-5.8)$ & $1.5(0.3-5.0)$ & 0.871 \\
Trombosit sayısı $(150-450 \mathrm{~K} / \mathrm{ul})$ & $212.0(74.0-549.0)$ & $195.0(105.0-384.0)$ & 0.509 \\
LDH $(126-222 \mathrm{U} / \mathrm{L})$ & $265.0(123.0-2433.0)$ & $196.0(132.0-544.0)$ & 0.001 \\
Troponin $(0-17.5 \mathrm{ng} / \mathrm{L})$ & $3.1(2.3-9722.0)$ & $2.3(2.3-8.7)$ & 0.001 \\
PCT $(0-0.5 \mathrm{ug} / \mathrm{L})$ & $0.62(0.05-10.0)$ & $0.05(0.05-0.15)$ & 0.001 \\
Ferritin $(23.9-336.2 \mathrm{ng} / \mathrm{ml})$ & $288.5(3.4-1544)$ & $60.0(4.0-268.6)$ & 0.001 \\
D-dimer $(0-500 \mathrm{ng} / \mathrm{ml})$ & $442.0(137.0-24100.0)$ & $256.0(98.0-925.0)$ & 0.001 \\
CRP $(0-8 \mathrm{mg} / \mathrm{L})$ & $14.3(1.0-425.0)$ & $4.1(1.0-74.0)$ & $\mathbf{0 . 0 0 1}$ \\
\hline LDH: Laktat dehidrogenaz, CRP: C-reaktif protein, PCT: Prokalsitonin. & & \\
\hline
\end{tabular}

Tablo IV. Akciğer BT Tutulum Düzeyine Göre Laboratuvar Parametrelerinin Karşılaştırılması

\begin{tabular}{lcccr}
\hline & $\begin{array}{c}\text { Hafif tutulum } \\
(\mathbf{n}=102)\end{array}$ & $\begin{array}{c}\text { Orta tutulum } \\
(\mathbf{n}=15)\end{array}$ & $\begin{array}{c}\text { Ağır tutulum } \\
(\mathbf{n}=13)\end{array}$ & $\mathbf{p}$ \\
\hline $\begin{array}{l}\text { Lökosit sayıSI } \\
(3.5-10.2 \mathrm{~K} / \mathrm{ul})\end{array}$ & $6.0(2.9-22.0)$ & $5.7(3.6-15.7)$ & $6.2(2.7-21.7)$ & 0.574 \\
$\begin{array}{l}\text { Lenfosit sayıs } \\
(0.9-2.9 \mathrm{~K} / \mathrm{ul})\end{array}$ & $1.5(0.2-5.8)$ & $1.0(0.5-3.7)$ & $700(0.6-2.6)$ & 0.002 \\
$\begin{array}{l}\text { Trombosit sayıs } \\
(150-450 \mathrm{~K} / \mathrm{ul})\end{array}$ & $225(87-451)$ & $188(109-395)$ & $157(74-549)$ & 0.025 \\
$\begin{array}{l}\text { LDH } \\
(126-222 \mathrm{U} / \mathrm{L})\end{array}$ & $245.0(123.0-2433.0)$ & $339(229-486)$ & $409(221-645)$ & 0.001 \\
$\begin{array}{l}\text { Troponin } \\
(0-17.5 \mathrm{ng} / \mathrm{L})\end{array}$ & $2.8(2.3-977.0)$ & $5.5(2.3-9722.0)$ & $8.7(2.3-48.0)$ & 0.001 \\
$\begin{array}{l}\text { PCT } \\
(0-0.5 \mathrm{ug} / \mathrm{L})\end{array}$ & $0.05(0.05-10.0)$ & $0.11(0.05-0.30)$ & $0.61(0.06-2.8)$ & 0.001 \\
$\begin{array}{l}\text { Ferritin } \\
(23.9-336.2 \mathrm{ng} / \mathrm{ml})\end{array}$ & $70.2(3.4-1274.0)$ & $306.1(7.0-1544.0)$ & $409.0(21.0-1500.0)$ & 0.001 \\
$\begin{array}{l}\mathrm{D}-\mathrm{dimer} \\
(0-500 \mathrm{ng} / \mathrm{ml})\end{array}$ & $378.0(137.0-4330.0)$ & $887.0(184.0-5600.0)$ & $1064.0(238.0-24100.0)$ & 0.001 \\
$\begin{array}{l}\mathrm{CRP} \\
(0-8 \mathrm{mg} / \mathrm{L})\end{array}$ & $8.6(1.0-425.0)$ & $57.8(4.2-112.0)$ & $85.1(4.4-329.0)$ & 0.001 \\
\hline LDH: Laktat dehidrogenaz, PCT: Prokalsitonin, CRP: C-reaktif protein. & & \\
\hline
\end{tabular}

\section{TARTIŞMA}

Literatürde COVID-19' da ANXA-1, ANXA-2, BMP-7 molekülleri ile ilgili çalışma bulunmamaktadır. Çalışmamız, COVID-19'da bu üç molekülün ilişkisini inceleyen ilk çalışmadır.

Anneksinler viral enfeksiyonlarda, akciğer hasarında ve enflamasyonlarda immünmodülatör role sahip protein ailesidir ${ }^{11}$. ANXA-1, ANXA-2, ANXA-5 ve ANXA-6'nın influenza $A$ virüs (IAV) enfeksiyonunun aracılık ettiği enflamasyon ve akciğer hasarında rol oynadı- 


\begin{tabular}{|ccccccccccc}
\hline \multicolumn{1}{l}{ Tablo V. BMP-7, ANXA-1, ANXA-2'nin Laboratuvar Parametreleri ile Korelasyonu } \\
\hline \multicolumn{1}{c}{ Lökosit } \\
& sayısi & Lenfosit & Trombosit & LDH & Troponin & PCT & Ferritin & D-dimer & CRP \\
\hline ANXA-1 & $\mathrm{r}$ & -0.005 & 0.067 & -0.097 & -0.023 & -0.070 & -0.083 & 0.088 & -0.032 & -0.014 \\
& $\mathrm{p}$ & 0.949 & 0.382 & 0.203 & 0.769 & 0.359 & 0.278 & 0.247 & 0.680 & 0.857 \\
ANXA-2 & $\mathrm{r}$ & 0.172 & 0.043 & 0.074 & 0.266 & 0.296 & 0.168 & 0.250 & 0.277 & 0.341 \\
& $\mathrm{p}$ & $\mathbf{0 . 0 2 3}$ & 0.577 & 0.412 & $\mathbf{0 . 0 0 1}$ & $\mathbf{0 . 0 0 1}$ & $\mathbf{0 . 0 2 7}$ & $\mathbf{0 . 0 0 1}$ & $\mathbf{0 . 0 0 1}$ & $\mathbf{0 . 0 0 1}$ \\
BMP-7 & $\mathrm{r}$ & -0.114 & 0.065 & -0.167 & -0.048 & -0.045 & -0.104 & 0.029 & -0.130 & -0.058 \\
& $\mathrm{p}$ & 0.137 & 0.399 & 0.128 & 0.537 & 0.556 & 0.173 & 0.703 & 0.089 & 0.449 \\
\hline
\end{tabular}

ANXA-1: Annexin-A1, ANXA-2: annexin-A2, BMP-7: Kemik morfogenetik protein-7.

ğının bildirildiği çalışmalar mevcuttur ${ }^{11-13}$. Ancak COVID-19 enfeksiyonundaki etkisi bilinmemektedir. Damazo ve arkadaşlarının bleomisin kaynaklı akciğer fibrozundan etkilenen hayvanlarda ANXA-1 tedavisi vererek yaptıkları deneysel çalısmada, ANXA-1' in hem enflamasyonu hem de fibrozisi iyileştirdiği gösterilmiştir ${ }^{14}$. Bu veriler, akciğer enflamasyonu ve fibrozis ile ANXA-1 arasında bir ilişki olduğunu düşündürmektedir ${ }^{14}$.

ANXA-1, anti-enflamatuvar özellik gösterirken, ANXA-2 pro-enflamatuvar özellikte olup bu iki molekül birbirlerine zıt etki etmektedir ${ }^{15}$. ANXA-2'nin, IAV enfeksiyonlarında viral replikasyonu arttırdığı ve CMV enfeksiyonunu kolaylaştırdığı bildirilmiştir ${ }^{11,16}$. ANXA-2'nin akciğer hasarındaki rolü ile ilgili çalışmalar mevcuttur ${ }^{8,16,17}$. Çalışmamızda da hastalarda ANXA-1 ve ANXA-2 düzeylerinin kontrol grubundan yüksek saptanması COVID-19'daki enflamatuvar süreç ile ilişkilendirilmiştir.

COVID-19'da akciğer tutulumunun yoğunluğu ile korele olacak şekilde antifibrotik olan ANXA-1'in azalması, fibrotik bir molekül olan ANXA-2'nin artması beklenir. Çalışmamızda beklendiği gibi fibrotik bir molekül olan ANXA-2 düzeyi akciğer tutulum seviyesi arttıkça istatistiksel olarak anlamlı düzeyde yüksek saptanmışır. Anti-fibrotik bir molekül olan ANXA-1 seviyesi ise akciğer tutulum düzeyi arttıkça azalmıştır, ancak bu azalma istatistiksel olarak anlamlı bulunmamıştır. Azalmanın istatistiksel olarak anlamlı olmaması akciğer tutulum seviyesine göre hastalarımızın eşit dağılmaması ile ilişkilendirilebilir.

Diğer taraftan BMP'ler, hasar sonrası doku homeostazının ve rejenerasyonunun sürdürülmesi için gereklidir. Akciğerdeki alerjik enflamasyon varlığında BMP-7'nin koruyucu bir rol oynadığı ve TGF- $\beta 1^{\prime}$ in pro-fibrotik etkilerine karşı olduğu bilinmektedir. Stumm ve arkadaşları, akut ve kronik astımlı hastalar üzerinde yaptığı çalışmada ${ }^{18}$, BMP-7 sinyali bloke edildiğinde akciğer fibrozisinin artıığını göstermiştir. Bu konu ile ilgili birçok çalışma vardır $^{19-21}$. Renal ve hepatik fibrozis ile ilişkisi kanıtlanan BMP-7'nin, pulmoner fibrozis üzerine etkisi net olarak bilinmemektedir.

Çalışmamızda BMP-7'nin hastalarda kontrolden yüksek saptanması, COVID-19'daki enflamatuvar süreç ile ilişkilendirilebilir. Antifibrotik bir molekül olan BMP-7'nin akciğer tutulum seviyesi ile korele şekilde azalması beklenir. Ancak çalışmamızda akciğer tutulumu ile BMP-7 arasında bir ilişki saptanmamıştır. Bu durum akciğer tutulum seviyesine 
göre hastalarımızın eşit dağılmamasıyla ilişkilendirilebileceği gibi BMP-7'nin pulmoner fibrozisteki etkisinin net olmamasıyla ilgili olabilir.

Bu çalışmanın kısıtlılıkları; akciğer tutulumuna göre hasta sayılarının dengeli dağılmaması, bu hastaların yalnız başvuru anında alınan tek serum örneği ile çalışma yapıımasıdır.

Sonuç olarak, günümüzde COVID-19 patogenezini anlamak ve yeni tedavi hedeflerini araştırmak için moleküler çalışmalara gereksinim vardır. ANXA-2 düzeyinin değerlendirilmesi COVID-19'a bağlı akciğer tutulum düzeyini öngörmede önemli olabilir.

\section{ETIK KURUL ONAYI}

Bu çalışma Selçuk Üniversitesi Tıp Fakültesi Yerel Etik Kurul onayı ile gerçekleştirildi (Karar No: 2020/307 ve Tarih: 10.07.2020).

\section{ÇIKAR ÇATIŞMASI}

Yazarlar bu makale ile ilgili herhangi bir çıkar çatışması bildirmemişlerdir.

\section{KAYNAKLAR}

1. Jin $Y$, Yang $H$, Ji W, Wu W, Chen S, Zhang W, et al. Virology, epidemiology, pathogenesis, and control of COVID-19. Viruses 2020; 12(4): 372.

2. Tovar I, Guerrero R, López-Peñalver JJ, Expósito J, Ruiz de Almodóvar JM. Rationale for the use of radiationactivated mesenchymal stromal/stem cells in acute respiratory distress syndrome. Cells 2020; 9(9): 2015.

3. Lai $T$, Li Y, Mai Z, Wen X, Lv Y, Xie Z, et al. Annexin A1 is elevated in patients with COPD and affects lung fibroblast function. In J Chron Obstruct Pulmon Dis 2018; 13: 473-86.

4. Ansari J, Kaur G, Gavins F. Therapeutic potential of annexin A1 in ischemia reperfusion injury. In J Mol Sci 2018; 19(4): 1211.

5. Galvão I, de Carvalho RVH, Vago JP, Silva ALN, Carvalho TG, Antunes MM, et al. The role of annexin A1 in the modulation of the NLRP3 inflammasome. Immunology 2020; 160(1): 78-89.

6. Sharma MC. Annexin A2 (ANX A2): An emerging biomarker and potential therapeutic target for aggressive cancers. Int. J. Cancer 2018; 144(9): 2074-81.

7. Luo M, Hajjar K. Annexin A2 System in Human Biology: Cell Surface and Beyond. Semin Thromb Hemost 2013; 39(4): 338-46.

8. Schuliga M, Jaffar J, Berhan A, Langenbach S, Harris T, Waters D, et al. Annexin A2 contributes to lung injury and fibrosis by augmenting factor Xa fibrogenic activity. Am J of Physiol Lung Cell Mol Physiol 2017; 312(5): L772-L782.

9. Carlson FR Jr, Bosukonda D, Keck PC, Carlson WD. Multiorgan damage in patients with COVID-19. JACC Basic Transl Sci 2020; 5(11): 1145-8.

10. Weiskirchen R, Maurer SK BMP-7 counteracting TGF-beta1 activities in organ fibrosis. Front Biosci (Landmark Ed.) 2013; 18: 1407.

11. Ampomah PB, Kong WT, Zharkova O, Chua SCJH, Perumal Samy R, Lim LHK. Annexins in influenza virus replication and pathogenesis. Front Pharmacol 2018; 9: 1282.

12. Schloer S, Hübel N, Masemann D, Pajonczyk D, Brunotte L, Ehrhardt C, et al. The annexin A1/FPR2 signaling axis expands alveolar macrophages, limits viral replication, and attenuates pathogenesis in the murine influenza A virus infection model. FASEB J 2019; 33(11): 12188-99.

13. Arora $S$, Lim $W$, Bist $P$, Perumalsamy $R$, Lukman HM, Li F, et al. Influenza $A$ virus enhances its propagation through the modulation of Annexin-A1 dependent endosomal trafficking and apoptosis. Cell Death Differ 2016; 23(7): 1243-56. 
14. Damazo AS, Sampaio AL, Nakata CM, Flower RJ, Perretti M, Oliani SM. Endogenous annexin A1 counterregulates bleomycin-induced lung fibrosis. BMC Immunol 2011; 12: 59.

15. Haridas V, Shetty P, Sarathkumar E, Bargale A, Vishwanatha JK, Patil V, et al. Reciprocal regulation of proinflammatory Annexin A2 and anti-inflammatory Annexin A1 in the pathogenesis of rheumatoid arthritis. Mol Biol Rep 2018; 46(1): 83-95.

16. Derry MC, Sutherland MR, Restall CM, Waisman DM, Pryzdial ELG. Annexin 2-mediated enhancement of cytomegalovirus infection opposes inhibition by annexin 1 or annexin 5. J Gen Virol 2007; 88 (pt 1): 19-27.

17. Lei Y, Wang K, Li X, Li Y, Feng X, Zhou J, et al. Cell-surface translocation of annexin A2 contributes to bleomycin-induced pulmonary fibrosis by mediating inflammatory response in mice. Clinical Sci (Lond) 2019; 133(7): 789-804.

18. Stumm CL, Halcsik E, Landgraf RG, Camara NOS, Sogayar MC, Jancar S. Lung remodeling in a mouse model of asthma involves a balance between TGF- $\beta 1$ and BMP-7. PLoS ONE 2014; 9(4): e95959.

19. Yang G, Zhu Z, Wang Y, Gao A, Niu P, Tian L. Bone morphogenetic protein-7 inhibits silica-induced pulmonary fibrosis in rats. Toxicology Lett 2013; 220(2): 103-8.

20. Myllärniemi M, Lindholm P, Ryynänen MJ, Kliment CR, Salmenkivi K, Keski-Oja J, et al. Gremlin-mediated decrease in bone morphogenetic protein signaling promotes pulmonary fibrosis. Am J Respir Crit Care Med 2008; 177(3): 321-29.

21. Murray LA, Hackett TL, Warner SM, Shaheen F, Argentieri RL, Dudas P, et al. BMP-7 Does not protect against bleomycin-linduced lung or skin fibrosis. PLoS One 2008; 3(12): e4039. 